\title{
ACCIDENT-PRONE AREA STUDY ON THE STREET CIAWI PUNCAK BOGOR
}

\author{
* Primadi Candra Susanto', Ryan Firdiansyah Suryawan², Hartono³, Budi Aji Purwoko ${ }^{4}$ \\ ${ }^{1}$ Institut Transportasi dan Logistik Trisakti, Jakarta, Indonesia \\ ${ }^{2}$ Sekolah Tinggi Penerbangan Aviasi, Jakarta, Indonesia \\ ${ }^{3,4}$ Pusat Penelitian dan Pengembangan Transportasi Jalan dan Perkeretaapian, Jakarta, Indonesia
}

*Coresponding author.

E-mail addresses: primstrisakti@gmail.com

\begin{abstract}
ARTICLE INFO
Article history:

Received:

3 March 2021

Accepted:

15 April 2021

Available online:

4 Mei 2021

ABSTRACT

The purpose of this research is to find out the location of the route that often occurs accidents in Puncak and to provide input to the local government, especially the Department of Transportation to guard the location to regulate traffic, Bogor is a strategic road that connects Cianjur and Bogor regencies, as well as a route that connects the tourism area. around Puncak, Bogor. The average effective lane width of Jalan Raya Puncak, Bogor is 4.2 meters, the capacity of Jalan Raya Ciawi-Puncak is 3565 pcu / hour. Supporting facilities for traffic activities are still lacking with a ratio of 7 signs per kilometer in both directions, 119 warning signs consisting of 16 prohibited signs, 24 directive signs, 5 command signs and as many warning signs. 74 pieces. The research method is descriptive quantitative research, is a literature study and uses primary and secondary data from related agencies. This research is supported by the spot speed (local speed) is the instantaneous velocity on a certain part of the road at a fairly short distance or at a certain point. Spot speed can be measured among others by directly using a radar meter (speed gun). The results of direct observations in the field show that road equipment facilities on the Raya Puncak Bogor road section, especially for road sign facilities, are still lacking.
\end{abstract}

Keyword: Area, Prone, Accident

\section{INTRODUCTION}

Traffic accidents are one of the big problems in every city. This is due to the increase in population and the increasing number of people who are traveling (traveling). The existence of a well-planned road is a good solution to be able to reduce the problem of accidents, because this can provide better safety and can reduce the number of misperceptions and concentrations in running a vehicle. Traffic accidents generally occur due to various causes simultaneously, namely humans, road conditions, vehicle conditions, weather, obstructed views, but driver error is a major factor in many road transport traffic accidents, among others due to fatigue, negligence, carelessness, boredom. Drivers can be in various conditions that threaten traffic safety, for example: lack of anticipation, carelessness, sleepiness, drunkenness, ignoring the distance to the vehicle in front of them.

In Bogor Regency itself, most of the highest total accidents occurred on primary arterial roads in the city. This is because the primary arterial roads are not only a crossing lane but also as access to meet the 
transportation needs of the local population. Judging from the condition of the road surface in Bogor Regency, repairs still need to be done. Because many roads have been damaged. Where the damage can be the cause of an accident. Puncak Tourism Area, Bogor is one of the capital's color destinations for recreation, especially on weekends. The peak area is 70 kilometers south of Jakarta. After identifying the data from the Dishub Kab. Bogor then can be known. From the initial identification data, the road section with the most frequent accidents is the Ciawi-Puncak highway, Bogor, where the Ciawi-Puncak highway is a crossing route to the Puncak tourism area and is also a district / city crossing road that can be used as a transitional route from one city to another. Where is the transitional route between Bogor-Cianjur-Sukabumi-Bandung which has the characteristics of roads with high volume and small road capacity as well as fairly extreme geographical conditions.

In the discussion of blackspot analysis at this time, there are several issues that become the main problem. Mitigation Problems in the study area are as follows: (1) Increase in traffic volume on Jl. Raya Ciawi-Puncak during weekends and long holidays. (2) Lack of safety facilities in the form of signs, markers and other facilities in the form of pedestrians (sidewalks) on Jl. Raya Ciawi-Puncak around the Tourist Attraction Location. (3) The high speed of vehicles passing Jl. Raya Ciawi-Puncak from the Peak to Gadog / Bogor due to downhill road conditions. (4) The need for traffic control at activity centers such as Cisarua Market and Several Rest Areas along Jalan Ciawi-Puncak. (4) The need for School Safe Zone facilities in front of the Primary School on Jl. Raya Ciawi-Puncak. (5) The number of side obstacles at each leg of the intersection, resulting in decreased performance of the intersection where there are frequent queues and vehicle delays. (6) The number of public transports that pick up, drop off and wait for passengers along the Ciawi-Puncak Bogor road; and (7) The large number of people crossing Jalan Ciawi-Puncak but not yet equipped with adequate road safety facilities.

The condition of the roads on the Ciawi-Puncak highway has a poor surface, and there are still lack of facilities - traffic safety facilities, pedestrians, and lack of infrastructure for street lighting. Another cause that can be put forward is the lack of awareness of the population about traffic order, so that many accidents involve pedestrians and slow vehicles. Accidents that occur in Bogor Regency, especially on the Ciawi-Puncak road section, Bogor need to be conducted a study as a reference in determining the effective and efficient prevention efforts. For this reason, it is necessary to make a report that can carry out the preventive steps more effectively later.

According to (Law of the Republic of Indonesia Number 22 of 2009 concerning Road Traffic and Transportation, 2009) Law of the Republic of Indonesia Number 22 of 2009 what is meant by: Roads are all parts of the Road, including complementary buildings and equipment designated for public traffic., which is at ground level, above ground level, below ground level / or water, as well as above water level, except rail and cable roads. Traffic signs are parts of Road equipment in the form of symbols, letters, numbers, sentences, and / or combinations that serve as warnings, prohibitions, orders, or directions for road users. A road marking is a sign that is on the road surface or on the road surface which includes equipment or signs forming longitudinal, transverse, oblique lines, as well as symbols that serve to direct the flow of traffic and limit areas of traffic interest. Traffic signaling devices are electronic devices that use light signals that can be equipped with sound signals to regulate traffic of people and / or vehicles at intersections or road sections. Several studies on traffic accidents on the Bogor peak highway have also been conducted (Chrisdianto et al., 2015; Nasution, 2019; Ryanto, 2019; Sudiatmono \& Santosa, 2010).

In road safety terminology, there are two strategies to improve safety, namely a traffic accident prevention strategy and a traffic accident reduction strategy (Sudiatmono \& Santosa, 2010). Accident prevention is oriented towards improving traffic safety, which is carried out through improving road geometry design, while accident reduction is oriented towards handling existing problems. Based on a predetermined route. Based on the preliminary survey, the average vehicle speed is known to be around $40 \mathrm{~km} /$ hour, so the observation distance for the spot speed survey (according to Bina Marga regulation No. 001 / T / BNKT / 1990) is $50 \mathrm{~m}$. Along with the increasing production of motorized vehicles, it is not uncommon to find problems that arise in road traffic, with road traffic conditions so busy that they often cause congestion and accidents (Aswan et al., 2006).

The number of accidents in Indonesia has increased every year. Understanding Accidents are unexpected events. Classification of Accidents: Light traffic accidents, moderate traffic accidents, heavy traffic accidents, according to the fact that one of the causes of accidents is because the motorists (humans) do not obey the regulations, the lack of accident signs and the physical condition of the road. Based on these data, the main steps that need to be taken to overcome the risk of traffic accidents are to determine and analyze accident-prone 
areas (black sites) and traffic black spots (Ryanto, 2019). From the problems that arise regarding traffic accidents, it is necessary to have the right solution to minimize and anticipate traffic accidents.

Some of the solutions that can be given include the following: Installing warning signs at blackspot locations, Installing road medians so that drivers avoid front-to-front collisions, Installing pedestrian light controlled crossings equipped with rumbling ribbons for pedestrians, Observation of police officers on a regular basis. periodically at blackspot locations (Widiyanti, 2016). Identification of vulnerable locations is called the "Hazard Indicator Counting Method", which is by comparing the "severity value" from year to year. The value of the severity level is obtained from the number of hazard indicators raised by the parameters (Fahza \& Widyastuti, 2019).

In improving traffic safety on the road, there are three parts that are interconnected with traffic operations, namely: drivers, vehicles and roads. The existing accident data from Jasa Marga from year to year shows that the biggest cause of accidents is caused by human factors (drivers). The cause of the accident that was carried out done because the vehicle, especially the road (geometric) has very little effect. This contradicts the fact that traffic engineers can only control one part, namely; Highway. Traffic accidents need greater attention, safety, smoothness and safety of road users are factors that are disrupted when an accident occurs. Road accidents always have an impact on the damage to motorists who are involved in the accident. In addition, accidents result in losses for accident victims and road users in the vicinity (Sekaryadi et al., 2019).

An accident is an event that is caused by many factors, which are basically due to the ineffectiveness of the main factors, namely road users / humans, vehicles, roads and the environment (Sairo et al., 2018). Speed is the speed of travel, usually expressed in kilometers per hour ( $\mathrm{Km} /$ hour) and is generally divided into three types, namely as follows (Teuku, 2017): Local speed (spot speed) is the speed of the vehicle at one time measured from a specified place. The running speed is the average speed of the vehicle on a line when the vehicle is moving and is obtained by dividing the length of the lane divided by the length of time the vehicle is moving along the route. Journey speed is the effective speed of a vehicle traveling between two places, and is the distance between two places divided by the length of time the vehicle completes the journey between these places, with this length of time covering each stop time caused by the time of the obstacle delay) traffic. Collecting local speed data (spot speed) is done manually, using surveyors by placing two surveyors on the upstream and downstream links of each (Haqqi et al., 2017).

\section{METHODS}

The research methodology is a plan that clearly states the rules and procedures for analyzing the required data and ensures that the assessment process is relevant to the problem of investigation in addition to the use of more efficient procedures. In data analysis using primary survey data and secondary data as a complement to primary data. This type of research used in this research is descriptive quantitative research. It is said to be quantitative because it uses an empirical study approach to collect, analyze, and display numerical or numeric data. And including descriptive research because it describes systematically the meaning and results of the data obtained.

The mindset of this study with the following explanations: (1) Input the current condition of the accidentprone areas on the Ciawi-Puncak Bogor road at this time. (2) The research subjects who were the research subjects (data sources) were the Bogor Regency Transportation Agency and the Bogor Regency Public Works Office, and the Police. (3) The research object which becomes the object of research is on the Ciawi-Puncak Bogor road related to accident-prone areas related to the provisions / regulations in force. (4) The method in this research will use descriptive qualitative analysis methods and quantitative descriptive, while for primary data collection is done by making observations in the field using hawyeke cancellation. (5) The output of this research is identified accident-prone areas of the completeness of road facilities and recommendations for these accident-prone areas. (6) The output is to improve the safety and security of the Ciawi-Puncak Bogor road, so as to reduce the number of road accidents.

\section{Data Collection Techniques}

Data is needed as material for information and evaluation of the conditions at issue. Secondary data required as material for analysis in this study are: Traffic Accident Data, Population Total Population of Bogor Regency; and daily traffic volume, Transportation Agency Kab. Bogor. Meanwhile, primary data collection is carried out based on the results of field observations in the accident-prone area on Jalan Ciawi-Puncak Bogor 
including: Road Inventory Survey, Accident-Prone Location Identification, Instantaneous Speed Survey and Traffic Conflict Survey. Field study by observing directly in the study object area with observation, observation and research of an object or direct activity.

\section{Method of collecting data}

This research is a literature study and uses primary and secondary data from related agencies in the study of documents regarding legality / policies and applicable laws and regulations relating to accident-prone areas. Meanwhile, to see the existing conditions is done through observation / observation using Hawkeye equipment.

\section{Calculation of local speed (spot speed)}

Local speed calculations are required to calculate the required deceleration and braking distance. The data needed for spot speed analysis is the travel time survey data.

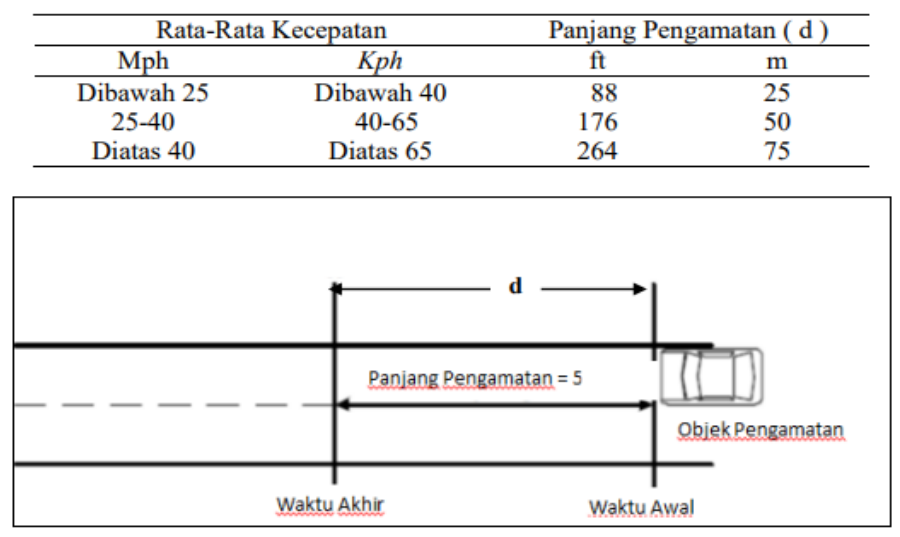

Figure 1 Spot Speed Survey Observation

The steps in observing the spot speed survey are: (1) Prepare survey equipment and forms to be used. (2) Determine the starting and ending points along the route as well as the points considered to be control points. (3) Activating the stopwatch when the vehicle passes the specified starting point. (4) Time and distance readings are made at the designated control point to indicate the vehicle has passed. (5) When a delay occurs or the vehicle is forced to move slowly, the stop time is recorded using the second stopwatch, the location or distance and the cause of the delay (numeric codes can be used to identify the cause of congestion). (6) Deactivate the stopwatch when it reaches the end point of the study route so that data will be obtained which will later be used during data analysis.

The main objective of transportation system engineering is to find and determine the most optimum combination of transportation means and methods for their operation in a certain area. The problem faced by transportation is actually more complicated, namely involving a wider area with different types of cargo or passengers. Basically there are three main characteristics of traffic, namely: (1) Volume (Flow), namely the number of vehicles passing through a point at a given point. path per unit time, and therefore usually measured in units of vehicles per unit time. (2) Density, namely the average number of vehicles per unit length of motion at any one time in time. (3) Speed, namely the distance traveled by the vehicle per unit time. This speed consists of three components utama, yaitu : Spot speed, namely the instantaneous speed of the vehicle at one reference point (one point). The influencing factors are: a. Driver b. Vehicle c. Highway d. Traffic e. Environment.

Running speed, namely the average speed of the vehicle in terms of a certain distance when the vehicle is moving, is obtained by dividing the length of the road under review by the travel time. Journey speed, namely the effective speed of the vehicle during the trip between two destination points and is the distance between the two points divided by the total time taken from the vehicle during the trip where the time includes the stop time and the delay that occurs. Space Mean Speed The average speed of space $(\mathrm{km} / \mathrm{h})$. Time Mean Speed (Ut) The average speed of a vehicle passing a point or piece over a certain time interval (km / hour).

In this research, the analysis used is descriptive qualitative analysis and quantitative descriptive with reference to legality / policies and provisions of the prevailing laws and regulations, as well as referring to previous studies related to road equipment facilities. Includes: Macro Analysis, Macro analysis can be carried 
out in the following steps: (1) Looking at the characteristics of accidents on the National Highway of Jalan Raya Puncak, Bogor by identifying the pattern of accidents in general from the factors that cause them. (2) Determine the road segment with the highest score using the Z-score, AEK and BKA. After obtaining the most accident-prone road segments, then determining the most accident-prone points using the Cumulative Summary method. Micro Analysis, After the location of the most vulnerable point (black spot / black section) is known with the results of macro analysis, then a more detailed analysis is carried out with micro analysis to obtain a violation diagram. A collision diagram in the accident data is needed to show: Time of incident, severity of accidents on road users, types of accidents, pedestrian facilities; and Analysis of conflict data. The statistical analysis performed to process the spot speed survey data was the 85th percentile (P85).

According to Abraham in Cindy (2013), 85 percentile speed is a traffic speed where $85 \%$ of drivers drive their vehicles on the road without being affected by lower traffic speeds or bad weather. In other words, the 85th percentile speed is the speed used by the 85th percentile of drivers which is expected to represent the speed that drivers often use in the field (Sendow, 2004). So, the purpose of this method is to determine the ideal speed limit on the road section under review based on the average speed of the vehicle. The survey using the spot speed was carried out at a point awal dan akhir pada setiap link dari rute yang telah ditentukan dan telah banyak dilakukan penelitiannya (Chrisdianto et al., 2015; Haqqi et al., 2017; Irfan, 2018; Mauliza et al., 2019).

\section{FINDINGS AND DISCUSSION}

Bogor Regency is one of the areas directly adjacent to the capital city of the Republic of Indonesia and geographically it is located at the position of 6019' ' 6047' south latitude and 10601 '- 1070103' east longitude. The area based on the latest data is $2,301.95 \mathrm{Km} 2$, with the following boundaries, (1) North: Depok City, (2) West: Lebak Regency, (3) East: Purwakarta Regency, and (4) South: Sukabumi Regency. Based on the results of the 2017 Socio-Economic Data Collection, Bogor Regency has 40 sub-districts, 427 villages / wards, 13,541 RTs and 913,206 households. Of these 234 villages have an altitude of less than $500 \mathrm{~m}$ above sea level (asl), 144 villages are between 500-700 m and the remaining 49 villages are around more than $500 \mathrm{~m}$ asl. Most of the villages in Bogor Regency have been classified as Swakarya villages, namely 236 villages, the other 191 are Swasembada villages and there are no Swadaya villages. Based on the regional classification, seen from the aspect of potential business fields, population density and social conditions, there are 199 urban villages and 228 rural villages.

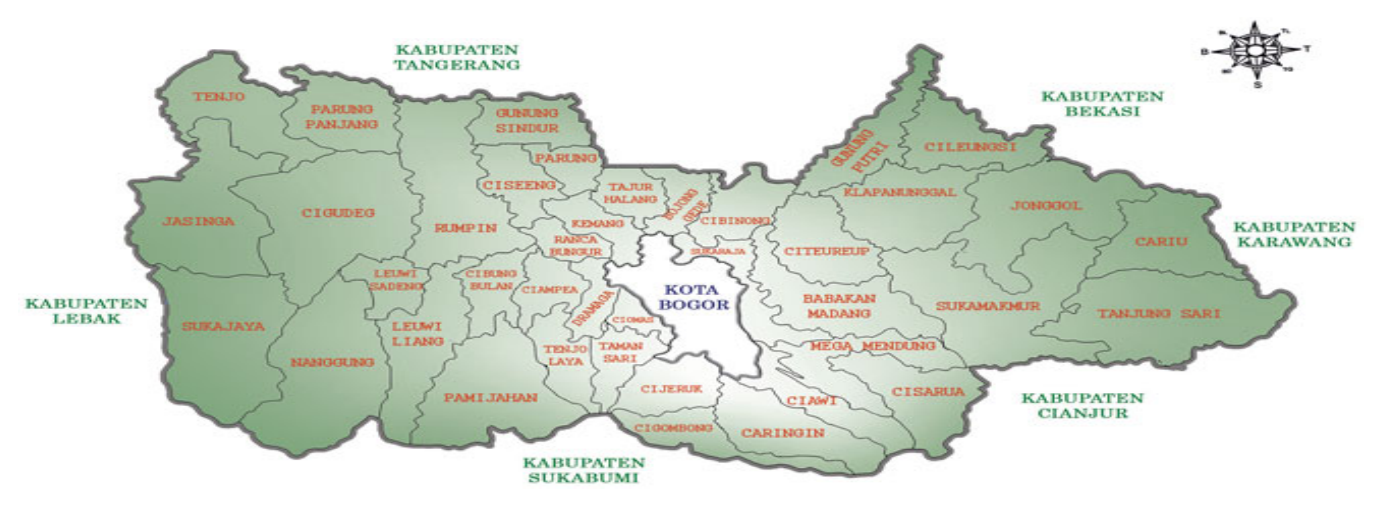

Figure 2 Map of District Administration, Bogor Regency

Bogor Regency is divided into development zoning which is the basis for the preparation of the development agenda and strategic plans for each development sector and program in the framework of balancing development between regions. The aims and objectives of regional development are to increase regional growth in a balanced manner between regions by utilizing resources optimally and sustainably. By considering regional characteristics and regional economic development, internal and external interaction patterns supported by service infrastructure networks both local and regional as well as policies for the development and distribution of population in a balanced manner according to the carrying capacity of the environment, the Bogor Regency area is divided into 3 (three) development areas. , namely: the western, central and eastern development areas. (1) Transportation conditions Road length $=1,790,060 \mathrm{~km}$. The road 
status is state roads $=72,444 \mathrm{~km}$ ( 3 sections) and provincial roads $=144,240 \mathrm{~km}$ ( 8 sections) and district roads $=1,300,740 \mathrm{~km}$ (251 sections). Good category road condition $=428,025 \mathrm{~km}$, medium category $=329,510 \mathrm{~km}$ lightly damaged category $=289,240 \mathrm{~km}$, heavily damaged category $=526,600 \mathrm{~km}$. (2) Condition of Road Infrastructure Road infrastructure is a section of roads around the construction site that describes the physical condition and land use and activities. side which affects the performance of these roads. (3) Jalan Raya CiawiPuncak Bogor The road that is the study location is Jalan Raya Ciawi-Puncak Bogor, where the status of the road is a national road and serves as the main road and the Ciawi-Puncak road section is an access in and out of Bogor Regency from the direction of Cianjur Residence with the characteristics of the speed and volume of vehicle traffic that is quite dense.

The Ciawi-Puncak road section has an undivided 2-lane 2-lane road type (2/2 UD). based on observations in the field, the effective lane width that should be used is 4.5 meters. With a population of under 500,000 people and a high enough level of side friction (such as: stopped vehicles, getting in and out of vehicles, as well as the activities of street vendors), the movement of vehicle movements on these roads is disturbed. The visualization and cross-section of the affected sections can be shown in the following figure.

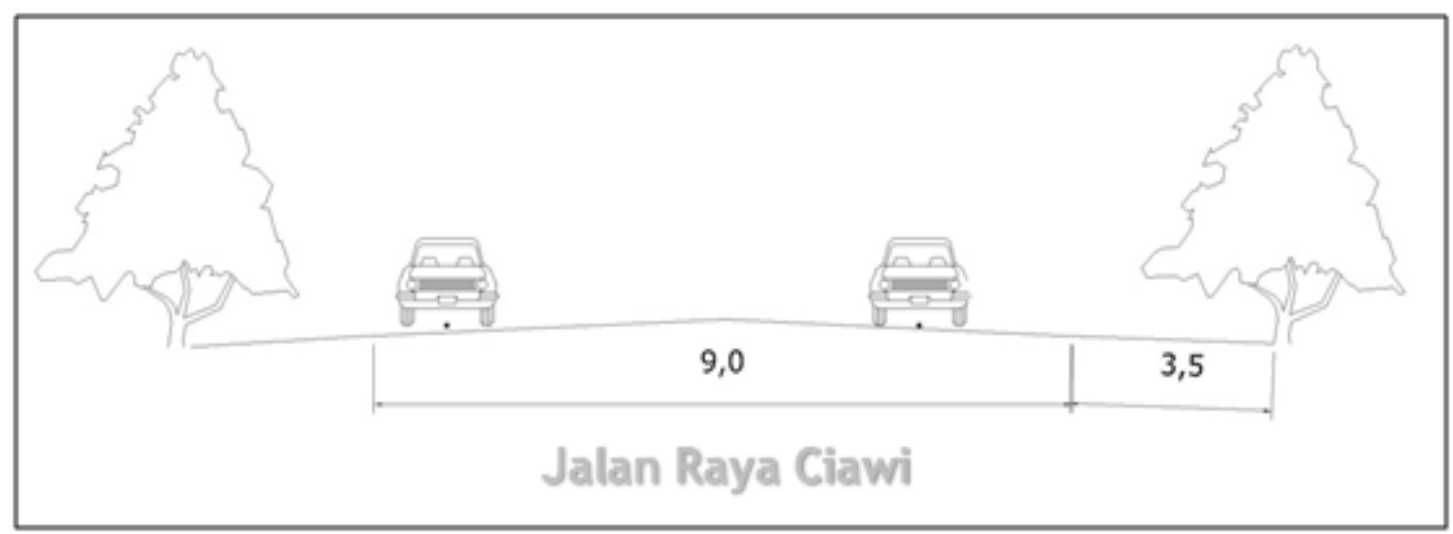

Figure 3 Visualization and Cross Section of Jalan Raya Ciawi-Puncak, Bogor

From the fluctuation above traffic Volume and V / C Ratio Segment mobility is an illustration of the level of ease of travel from a place of origin to a destination that passes through a road segment. Ease of travel shows the traffic performance on these roads, which in this study uses the V/ C ratio. From the results of the survey and analysis, it was obtained the volume and value of the $\mathrm{V} / \mathrm{C}$ ratio of the roads in the study location, namely on weekdays and afternoon rush hours which can be seen in the following table: Traffic Volume of Ciawi-Puncak Highway on Weekdays To determine traffic conditions on Jl. . Raya Ciawi, conducted a classified traffic enumeration survey and a road section inventory survey to determine traffic volume, capacity and $\mathrm{V} / \mathrm{C}$ ratio. From the observation in the field above, it is known that the traffic volume of Jalan Raya Ciawi-Puncak on a weekday with the direction of Puncak has a volume of $1323.55 \mathrm{pcu} /$ hour with a V/C Ratio of 0.37 and for Jalan Raya Ciawi-Puncak, the direction of Bogor is $2050.60 \mathrm{pcu} /$ hours with the highest $\mathrm{V} / \mathrm{C}$ ratio of 0.58 .

The side panel is known that the traffic volume on weekdays occurs at $07.00-08.00$ WIB where the volume at that hour is $2050.60 \mathrm{pcu} /$ hour. From the fluctuation above, it is known that the traffic volume during the morning hours occurs at 08.00 - 09.00 WIB where the volume at that hour is $1323.55 \mathrm{pcu} /$ hour. The composition of vehicles on Jalan Raya Ciawi on weekdays is dominated by motorbikes with a percentage of $50 \%$ and private cars as much as $27 \%$ and public passenger cars by $11 \%$. That the traffic on Jalan Raya Ciawi-Puncak on weekdays is dominated by motorbikes where motorbikes are still used as the main mode of travel for the community.

Traffic Volume on Jalan Raya Ciawi-Puncak on Holidays The Ciawi-Puncak highway is one of the roads leading to the peak from the direction of Ciawi and from the direction of Cianjur / Cipanas Regency so that on holidays or weekends there is an increase in traffic volume, especially on roads leading to Puncak . The increase in traffic volume is caused by the movement of people to take weekend holidays to the peak area. From the survey and analysis carried out, it is known that the traffic volume and V / C ratio on the CiawiPuncak Highway section. From the field observations in the table above, it is known that the traffic volume of Jalan Raya Ciawi-Puncak on holidays with the direction of Bogor has a volume of $1388.52 \mathrm{pcu} /$ hour with a V / C Ratio of 0.39 and for Jalan Raya Ciawi to the Peak of $2181.67 \mathrm{pcu} /$ hour with The highest V / C ratio was 0.61. From the fluctuation above, it is known that the volume of traffic on holidays occurs at $16.00-17.00$ 
WIB where the volume at that hour is $1388.52 \mathrm{pcu} /$ hour. From the fluctuation above, it is known that the volume of traffic during the early morning hours occurs at $08.00-09.00 \mathrm{WIB}$ where the volume at that hour is $2181.67 \mathrm{pcu} /$ hour.

On Jalan Raya Ciawi on holidays, motorbikes are dominated by a percentage of $48 \%$ and private cars as much as $28 \%$ and public passenger cars by $11 \%$. That the traffic on Jalan Raya Ciawi on holidays is dominated by motorbikes where motorbikes are still used as the main mode of travel for the community. The average road speed is the average vehicle speed calculated using the spot speed method. This method is used by calculating the average speed of each passing vehicle on each analyzed road segment The average speed of the vehicle is measured together with the calculation of the traffic volume during the observed peak hours. Average vehicle speed.

Accident Data Analysis as explained in the previous chapter, that in analyzing accident data on the national route of Jalan Raya Puncak, Bogor, it is aimed to identify the dominant causal factors of accidents based on the principle of recurring accidents that are relatively the same and caused by relatively the same causes. Basically, the analysis is divided according to the purpose of writing, namely: (1) Knowing the characteristics of accidents that occur on the National Road, Jalan Raya Puncak, Bogor by identifying general accident patterns from the factors that cause them. (2) Identifying accident-prone locations in the form of road accidents and traffic accident-prone points on National Road, Jalan Raya Puncak, Bogor and the order of priority; and (3) Providing recommendations for handling accident-prone locations in accordance with the problems of the sections studied.

Based on the accident data obtained, it is then analyzed further to see the characteristics of the existing accidents. Accident data analysis is divided into two stages, namely causal factor analysis: Data analysis is carried out to see the characteristics of accidents in general. For the analysis of this data will discuss: (1) General characteristics related to severity and time. (2) The characteristics of the people involved in the accident, seen from the driver and pedestrians, the characteristics of the vehicle involved in the accident, the characteristics of the road and the environment at the accident site. (3) Identification of Accident-Prone Locations of Accident-Prone Segments (Blacksite), Accident-Prone Points (Blackspots) In general, during the 2-year period, namely 2015-2016, there were 65 accidents that occurred on the national route, Jalan Raya Puncak, Bogor. the number of victims reached 101 people, both dead and injured.

\section{CONCLUSION AND RECOMMENDATION}

Efforts to handle accident-prone locations, based on general causative factors, especially at night, it is necessary to add road equipment such as public street lighting and warning signs. Based on human factors, it is necessary to increase education and knowledge for drivers in the form of socialization about safe traffic. Based on the vehicle factor, it is necessary to improve safety technology in vehicles and an effective roadworthiness test inspection. For the road factor, it is necessary to improve road infrastructure. Based on the identified problems, there are four alternative traffic management arrangements as an option in preventing accident-prone points. Blackspot analysis on Jalan Raya Puncak, Bogor. Based on the results of the direct survey in the field, some of the problems that arise can be explained.

The results of direct observations in the field show that the road equipment facilities on the Raya Puncak Bogor road section, especially for road sign facilities, are still lacking. Traffic safety on an urban road is a government success in designing a traffic system that is comfortable and safe. Increasingly rapid traffic and an increasing number of vehicles are not matched by adequate road capacity so that the road network does not function optimally and reduces traffic safety. The high volume of traffic causes the speed of the vehicle to be slow even though the speed of the vehicle is very much needed for the mobilization of goods and services.

\section{REFERENCES}

Aswan, E. N., Andi, R., \& Budi, A. (2006). Analisis Faktor Penyebab Kecelakaan Lalu Lintas Di Ruas Jalan Raya Puncak Bogor. Jurnal Online Mahasiswa (JOM) Bidang Teknik Sipil, 1(1), 1-10.

Chrisdianto, I., Mahmudah, A. M. H., \& Legowo, S. J. (2015). Perbandingan Estimasi Waktu Perjalanan Dari Instantaneous Model dan Time Slice Model Dengan Waktu Perjalanan Dari Metode Kendaraan Bergerak. Jurnal Matriks Teknik Sipil, 3(3), 654-662. https://doi.org/https://doi.org/10.20961/mateksi.v3i3.37262

Fahza, A., \& Widyastuti, H. (2019). Analisis Daerah Rawan Kecelakaan Lalu Lintas pada Ruas Jalan Tol Surabaya- 
Gempol. Jurnal Teknik ITS, 8(1), 54-59. https://doi.org/10.12962/j23373539.v8i1.42123

Haqqi, R., Marpaung, H. S., \& Sebayang, M. (2017). Analisis Waktu Tempuh Kendaraan Bermotor dengan Metode Estimasi Instantaneous Model (Studi Kasus: Jalan Pekanbaru-Bangkinang Km. 19 Sampai dengan Km. 25). Jom FTEKNIK, 4(2), 1-8.

Irfan, I. (2018). Pengaruh Hambatan Samping Terhadap Kecepatan Dan Arus Lalulintas. Jurnal Teknik Sipil Dan Teknologi Konstruksi, 3(4), 64-76.

Mauliza, R. I., Sabrina, T. B., \& Maulana, W. (2019). Pelanggaran Kecepatan Kendaraan pada Ruas Jalan Tol Cipularang. Jurnal Teknil Sipil, 5(1), 39-49.

Nasution, A. E. (2019). Analisis Faktor Penyebab Kecelakaan Lalu Lintas di Ruas Jalan Raya Puncak Bogor (Studi Kasus: Ruas Jalan Gadog-Pucak Pas). Jurnal Online Mahasiswa (JOM) Bidang Teknik Sipil, 1(1).

Ryanto, A. Y. (2019). Analisis Faktor Penyebab Kecelakaan Lalu Lintas di Kota Bogor (Studi Kasus : Ruas Jalan Raya Tajur). Jurnal Online Mahasiswa (JOM) Bidang Teknik Sipil, 1(1), 1-9.

Sairo, M. P. M. K., Muliawan, I. W., \& Aryastana, P. (2018). Analisa Faktor Penyebab Kecelakaan Pada Daerah Rawan Kecelakaan Di Ruas Jalan Sumba Barat -Sumba Barat Daya. Paduraksa, 7, 210-218.

Sekaryadi, Y., Setiawan, D., \& Nurhalim, I. (2019). Kajian korelasi kecelakaan dengan kepadatan lalu lintas di ruas jalan Cianjur-Sukabumi. Jurnal Momen, 2(2), 93-99.

Sudiatmono, D. P., \& Santosa, W. (2010). Upaya Penanganan Lokasi Rawan Kecelakaan Ruas Jembatan Cikundul Jalan Raya Puncak Jawa Barat. Jurnal Transportasi, $10(3), \quad 235$. https://doi.org/https://doi.org/10.26593/jt.v10i3.435.\%25p

Teuku, U. (2017). Pengaruh Hambatan Samping Terhadap Kecepatan Dan Arus Lalu Lintas. Jurnal Teknik Sipil Dan Teknologi Konstruksi, 3(4), 64-76. https://doi.org/https://doi.org/10.35308/jts-utu.v3i4.220

Undang-Undang Republik Indonesia Nomor 22 Tahun 2009 tentang Lalu Lintas dan Angkutan Jalan. (2009). UndangUndang Republik Indonesia Nomor 22 Tahun 2009 tentang Lalu Lintas dan Angkutan Jalan.

Widiyanti, D. (2016). Kajian Daerah Rawan Kecelakaan (DRK) di Kabupaten Musi Banyuasin. Jurnal Penelitian Transportasi Multimoda, 14(2), 67-76. 